UDC 811.163.41'373

811.163 '373

https://doi.org/10.18485/ms_zmskij.2021.69.2.4

Др Исидора Г. Бјелаковић

Др Милена С. Зорић

\title{
ЛЕКСИЧКИ СЛАВЕНИЗМИ И ПИТАњЕ ЖАНРА У СЛАВЕНОСРПСКОМ ЈЕЗИКУ*
}

Имајући у виду чињеницу да испитивања српских књижевнојезичких идиома 18. и 19. века показују да славенизми нису употребљавани само када је било потребно попунити тзв. ономасиолошке празнине, већ да је њихова употреба имала и особиту стилску функцију, централно питање које се поставља у овом тексту јесте питање функционализације славенизама и њиховог односа према жанру (књижевноуметничком, публицистичком, административном и научном), пре свега у славеносрпским текстовима, уз кратак уводни осврт на различита тумачења овог појма у србистици. Будући да су досадашња истраживања сличног профила имала углавном фрагментаран карактер, у раду се, поред синтетичког прегледа оног што је до данас на том пољу утврђено, указује и на могуће тенденције у оним жанровима који нису били предмет исцрпнијих анализа.

Кључне речи: славенизми, славеносрпски језик, жанр.

1. ПОЈАМ СЛАВЕНИЗМА У ДИЈАХРОНИЈСКОЈ СРБИСТИЦИ. ИаКО се У сЛавИстИЦи славенизми дефинишу као позајмљенице из словенских језика, у дијахронијској србистици овај термин има донекле сужено и измењено значење, које нажалост - још нема општеприхваћену и јединствену вредност: различити аутори, наиме, под овим термином подразумевају различите језичке појаве. ${ }^{1}$

1.1. СЛАВЕНИЗМИ У ПОСТАВКАМА Б. УНБЕГАУНА И Н. ТоЛСТОјА. Пишући о развоју књижевних језика код Срба у 18. и 19. веку, Б. Унбегаун (1995) и Н. И. Толстој (2004) славенизме посматрају као лексеме из рускословенско $\bar{\imath}$

* Рад је настао у оквиру пројеката Ист̄орија срӣской језика и Речник славеносрӣской јези$\kappa a$, који финансира Министарство просвете, науке и технолошког развоја Републике Србије.

${ }^{1}$ Више о тумачењима појма славенизам у србистици в. у Зорић 2013. 
језика, означавајући их прилично варијабилним и понекад неуједначеним терминолошким апаратом, чиме заправо покушавају да поставе дистинкцију у односу на русизме (позајмљенице из руског књижевног језика), често тешко уочљиву и фазичну када је реч о књижевним језицима Срба ове епохе. ${ }^{2}$ Поред термина славенизам, Н. Толстој се служи и формом нешто ширег значења - књищки елемениии, под којима подразумева рускословенске лексеме и хибриде ${ }^{3}$ (2004: 139).

1.2. ПојАМ СЛАВЕНИЗМА У ИСТРАЖИВАњИМА А. МЛАДЕНОВИЋА, П. ИвИћА И Љ. Суботић. За разлику од Б. Унбегауна и Н. Толстоја, А. Младеновић и П. Ивић под славенизмима подразумевају и рускословенску и руску лексику, дајући им недвосмислено статус позајмљеница и јасно их одвајајући од хибрида (Младеновић 1989: 109, 113; Ивић 1998: 139-141, 161, 194, 195). Прихватајући наведено тумачење, Љ. Суботић уводи квалификатор лексички уз термин славенизам како би га одвојила од славенизама на морфосинтаксичкој равни (нпр. перфекта без глаголске копуле) (Suвотіс́ 2006: 22, 23). Истовремено, А. Младеновић уочава и једну чињеницу, која у високом степену усложњава овакву интерпретацију лексичких славенизама. Он, наиме, напомиње да је немали број ових форми егзистирао и у српскословенском језику, чиме се заправо дестабилизује идеја о славенизмима као позајмљеном лексичком слоју (МлАдЕновић 1989: 114).

Попут Н. Толстоја, и Љ. Суботић издваја наткатегорију књищке речи (1989: 59, 94, 124), подразумевајући под њом целокупну лексику која није припадала дискурсу простонародног говора и није забележена у Вуковом Рјечнику, али је, као и славенизми, попуњавала празнине у лексикону, без обзира на њену старину и порекло (SUвотіс́ 2006: 29, 30).

1.3. ПојмовНА ВРЕДНОСт СЛАВеНИЗАМА У РАДОВИМА С. СтИјовИћА. Најшире одређење појма славенизам дао је С. Стијовић, којем он, уз форме из рускословенског и руског књижевног језика, придружује и српскословенске књишке форме, хибриде, па чак и йозајмљенице из других језика за које се

${ }^{2}$ Н. Толстој се, на пример, служи терминима руско-словенизми (2004: 76), словенизми који нису србуљског, него руской $\bar{u} и \bar{u} а$ (2004: 77), славенизми (2004: 96, 111), славенорусизми (2004: 96, 123), славенизми руске обојеносиии (2004: 98), ирквенословенизми (2004: 202).

3 Под хибридима или славеносрбизмима, познато је, подразумевају се лексеме у којима се истовремено може уочити присуство црта из различитих језичких идиома (српског, руског, рускословенског па и српскословенског), чија је генеза могла бити заснована на два модела:

(1) на фонетској и морфолошкој адаптацији, тј. посрбљавању форми из рускословенског и руског језика (нпр. сазвезяїе, саgержанїе, человбческойъ, човбчестиво, равноноћїе и др.), или

(2) на независном лексичком принављању (стварању неологизама), али не у складу са структуром и творбеним моделима српског језика, него комбинацијом различитих фонолошких, морфолошких и/или деривационих елемената (нпр. међупределъ - 'споредна страна ствета; любвесоперник и сл.) (в. МлАденовић 1982: 139; 1987: 48; 1989: 57, 91-92, 133; Стијовић 1992: 94; Suвотіс́ 2006: 22; МилАновић 2013; БЈелАковић 2017б: 52; Зорић 2018: 22). На овај начин су, како примећује Павле Ивић, настајале форме које не одговарају стању ни у једном од изворних језика (1998: 134, 135, 161-164; 2001: 183). 
могло утврдити да су ушле преко црквенословенских извора или руског језика (1992: 13; 22-23; 37-38).

2. ПОЈМОВНО ОДРЕЪЕњЕ ЛЕКСИЧКИХ СЛАВЕНИЗАМА, ПРЕДМЕТ И ЗАДАЦИ ИСТРАживАњА. Имајући у виду наведене интерпретације, под лексичким славенизмима (ма како појмовно и терминолошки били одређени) подразумевамо онај сегмент лексикона славеносрпског језика који га недвосмислено раздваја од народног језика вуковског типа, тј. онај слој ненародне лексике који је славеносрпском језику обезбеђивао ноту интелектуалног, европејског и узвишеног, а који је могао да буде и део наслеђа (из српскословенске писмености) и иновација (активирањем или принављањем преко рускословенског/ руског језика у 18. и 19. веку, односно независним креирањем неологизама хибридног типа), чиме је створен јединствен систем наслеђене и иновативне лексике.

Имајући у виду чињеницу да испитивања српских књижевнојезичких идиома 18. и 19. века показују да славенизми нису употребљавани само када је било потребно попунити тзв. ономасиолошке празнине, већ да је њихова употреба имала и особиту стилску функцију, централно питање које се поставља у овом тексту јесте питање функционализације лексичких славенизама и њиховог односа према жанру (књижевноуметничком, публицистичком, административном и научном) како би се уочила веза у погледу употребе славенизама и структуре појединих жанрова у српској писаној традицији 18. и 19. века, на чију се недовољну испитаност већ дуго указује (в. нпр. КРечMEP 2000). Будући да су досадашња истраживања сличног профила имала углавном фрагментаран карактер, овом приликом покушаћемо да дамо одређени синтетички преглед оног што је до данас на том пољу утврђено, али и да се осврнемо на могуће тенденције у оним жанровима који до сада нису били предмет исцрпнијих анализа.

\section{3. КњИЖЕВНОУМЕТНИЧКИ ТЕКСТОВИ}

3.1. СтруктурА. Будући да књижевноуметнички текстови најчешће нису јасно издиференцирани у структурном смислу, најуочљивију карактеристику у погледу односа структуре и употребе славенизама представља њихово упорно везивање за наслове, посвете и спискове пренумераната. Активирање славенизама у овим сегментима књижевних текстова има, међутим, и посебну ванструктурну димензију, која је у првом реду узрокована тежњом ка постизању узвишеног тона (нпр. због почетног, најпроминентнијег дела текста - наслова, посвете, предговора, или због жеље за изражавањем поштовања према представницима виших друштвених слојева - особама којима су књиге посвећене, меценама и пренумерантима).

3.2. ЖАнр. У досадашњим истраживањима уочено је да се већа концентрација славенизама везује за дела ненаративног профила, односно за оне текстове у којима је лексика апстрактног значења била неопоходна. Још је 
1970. године X. Куна (KunA 1970: 261; 270) указала на видну дивергенцију у Доситејевој употреби славенизама, која је зависила од жанра и тематике, а аналогну поставку дао је и С. Стијовић (1992: 119-125): наиме, у делима филозофског карактера, испеваних узвишеним тоном (нпр. у Његошевој Лучи микрокозма $)^{4}$, број славенизама далеко је већи него у наративним штивима или песмама написаним у духу фолклорне традиције, где се они готово и не појављују (нпр. у Кули Бурищића). Слична ситуација уочава се и у језику басни, у којима се, за разлику од првог (наративног) дела, веће груписање славенизама везује за другу целину, за тзв. наравоученија, чија алегоријска структура намеће потребу за већим бројем лексема апстрактног значења (в. Суботић 1994): 5

\section{ЗМІЯ И СЕЛЯНИНЬ.}

Змїю у време зиме полусмрзнуту наће селянинь, и изь некаквогъ старопреданнаго суевьрїа сажали о нїой унесе э у свой домъ и положи э подъ топлу пећь. А кадь се ова разгрїе и размрзне, почне по кући мотатисе звиждати и свою едъ просипати. селянинь видећи такову погану наравь и неблагодарность, истера э опеть на мразь гдесе она смрзне, и сконча свою едовиту ћудь.

\section{Наравоученїе.}

Достойно возмездїе и награжденїе злоћудна и неблагодарна човека, кои благодъянїе съ злодъянїемъ возмеждава. Злоба, коя мећу найгори варвари гнусна э и мрзска. Акоће се како човекъ за какованибудъ несрећна обстоятелства са свои прїятели завадити и раздвоити: нища манъ нека никада не смеће изь предъ очию времена любови и прїятелства. [...] Нища нїе способнїе вражду угасити и мрзость, колико воспоминанїе прежнъ любави. Но све э то всуе, кадъ э срце одъ младости изщећено и отровано. (ОБрадовић 1788: 93; пример одабрале и славенизме подвукле ауторке)

3.3. ТемАтикА. Истраживања указују и на то да је тематика књижевноуметничког текста у целини (или његових сегмената) релевантан параметар за утврђивање степена употребе славенизама: нпр. црквена тематика у роману Калућер Ј. Суботића несумњиво је допринела њиховом изразитијем активирању (в. МилАновић 2014: 325). Славенизми се, поред наведеног, у видно већем броју употребљавају и у оним сегментима једног књижевноуметничког

\footnotetext{
${ }^{4}$ На везу узвишеног стила у Лучи микрокозми и употребе славенизама указује и Б. Дабић (1982: 48).

${ }^{5}$ Апстрактност значења представља, дакле, идеалан предуслов за активирање славенизама, што је регистровано је и у другим књижевноуметничким текстовима, чак и у оним насталим под окриљем каснијих епоха, у којима славеносрпски више нема улогу актуелног књижевног језика, него уметничког средства за оживљавање прошлости (нпр. код С. Сремца; в. Јовић 1997: 153).
} 
дела у којима је реч о домену религиозног, те о контексту јавне комуникације - у цркви, школи, званичним институцијама и сл. (в. Јовић 1997: 154).

\section{4. СЛАВЕНИЗМИ У ФУНКЦИЈИ СТИЛЕМА У КњИЖЕВНИМ ДЕЛИМА}

3.4.1. СЛАВЕНИЗМИ КАО ИНСТРУМЕНТ ЗА ПОСТИЗАњЕ КОМИЧНОГ ЕФЕКТА. КаДа је реч о драмским текстовима, ${ }^{6}$ Б. Клаић је још 1961. године писао о славенизмима у функцији смеха у Стеријиним комедијама, где се комички ефеккай заснива на несиооразумима који йочивају на уйойреби славенизама: нпр. између Алексе и Марка, јунака Лаже и йаралаже (75-78). На основу фонолошке подударности/сличности са домаћим лексемама, Марко, наиме, често погрешно интерпретира значења славенизама које Алекса изговара (йаче > надимак Маркове бабе био је Паче; всује > Јелица и да $\bar{u} c y j e$, у Беч више неће ићи; нейли> щиунейле не продаје; и сл.). ${ }^{7}$ Поред тога, у служби комичног Стерија честу употребу славенизама једног јунака доводи у везу са свешћу о националној припадности и ставом у вези са тим: на пример, када Алекса користи речи попут слеgовайелно, яражајщии, хуgи, мњеније и сл., Марку потпуно непознате, овај закључује да барон Голић никако не може бити Србин. Комика заснована на језичком неспоразуму уочава се и у другим Стеријиним комедијама (нпр. у Поконяиреној йикви (Поповић 1838) Ружичић се Евици обраћа са: „Благозрачна Хелено“, а она га исправља да је њено име Евица, указујући тиме не само на неразумевање Ружичићевог славјанског језика него и на непознавање класицистичког песничког реквизитаријума).

3.4.1.1. Поред наведеног, славенизми у књижевноуметничким текстовима могу понети и функцију изазивања комично-ироничног ефекта. Таква употреба посведочена је, на пример, у Аутиобиоірафији Ј. Суботића ${ }^{8}$, али и код представника каснијих постславеносрпских времена (нпр. код С. Сремца; в. Јовић 1997: 157).

3.4.2. СЛАВЕНИЗМИ КАО ИНСТРУМЕНТ ЗА КАРАКТЕРИЗАЦИЈУ ЛИКОВА. ЈеЗИК КаО једно од основних средстава (уз понашање и радњу) у карактеризацији ликова служи за идентификацију позитивних и негативних јунака (Ромчевић 2004: 85). Ово је нарочито уочљиво у драмама. Тако, на пример, Ј. Стерија Поповић - као „прави мајстор језичке или вербалне комике“ (МАксимовић 2006: 210) користи одсуство, односно присуство славенизама у језику својих ликова као вид својеврсне позитивне, односно негативне карактеризације. Уврежено је мишљење да је језик његових негативних ликова контаминиран страним елементима (Ромчевић 2004: 85), али се у том случају поставља питање шта је са Евицом из Лаже и йаралаже, као и да ли је Фема негативан или

${ }^{6}$ Више о функцији славенизама у раним драмама Ј. С. Поповића в. у Зорић 2018.

7 Чувена реплика, написана у овом духу, у којој вечито гладни Мита уместо „абије“ (ogмax, већ) чује „гурабије“ - дописана је касније, као и неке друге сцене којима се појачава комични ефекат, а то је Стерија учинио тек пошто је Лажа и йаралажа заживела на сцени.

${ }^{8} \mathrm{~J}$. Суботић он пише: Заступници ти имају пре свега захтевати од господина Блажењејшаго... (в. МилАновић 2014: 326; подвукле ауторке) 
трагичан лик. Алекса и Мита из Лаже и йаралаже, чији језик обилује славенизмима, заиста јесу негативни јунаци, али Ружичић из Поконяирене тиикве јесте трагичан исто колико и Евица или Фема. Излаз и бег из свакодневице, за коју мисле да им не припада и у којој се осећају непожељно и страно, они траже носећи маску оличену у језику који није језик њихове средине.

Баш као што Алекса и Мита „мењају фарбу““ када нису сами и почињу да „славјанствују“, тако и Вук Бранковић са чистог народног језика прелази на језик препун славенизама оног трена када код Лазара почиње да сплеткари против Милоша Обилића у истоименој трагедији:

Ништа светла Круно, ништа, Турцы су на Косову, но ево ти напредъ прорыцанъ мое, с' отровомъ ће исходъ помешанъ быти. $O$ нещасної часа, каяъ се общейолезни совґиии не йослущаще, ужасноїъ майновенія, каg' су речи єgовитее іууе о ообренія иолучиле (Поповић 1828: 59-60).

Славенизми су, показало се на овим и сличним примерима, битан драматуршки елемент Стеријиних дела, како комедија тако и жалосног позорја Милощ Обилић. У његовим осталим жалосним позорјима (Наоg Симеон и Свешислав и Милева) они се нису функционализовали него су остали део класицистичког сентименталног и мелодрамског реквизитаријума, те одлика својеврсног средњег стила. Чињеница да у њима нема језичке карактеризације, а самим тим ни језичке диференцираности међу ликовима, допринела је томе да емотивни набој драме изостане, што је утицало на то да оне не одоле зубу времена.

3.4.2.1. Аналогни поступак уочен је и у другим прозним врстама каснијих епоха (нпр. у приповеткама и романима С. Сремца, у којима јунаци свесно употребљавају славенизме како би указали на припадност одређеном друштвеном сталежу, како би одавали утисак високе учености и сл. (в. Јовић 1997: 154-156)).

3.4.3. СЛАВЕНИЗМИ У ФУНКЦИЈИ ИЗБЕГАВАњА МОНОТОНИЈЕ И ПОСТИЗАњА ЕКСпРЕСИвности. Истраживања лирских и прозних текстова указују и на такву употребу славенизама при којој се њиховом навођењем уз домаће и др. синониме у истом тексту (чак и реченици) избегава монотонија, на пример:

У почетку прошастогь столбтія преселисе трговаць нбкій изъ Енглеске, по Имену Іонсонъ, у Петербургъ, новосазидану тада престолну варошь Русіє, да бы тамо дъла трговине своє іоштъ съ већомъ користи, него у свомъ отечеству отправляти могао. [...] Идите обоица домовини вашой, и будите свагда и свима угледъ чисте, блажене любови (Д. Исаиловић, Уранија, 1837; према Цветковић ТЕОфиловић 2006: 480);

Она се ніє усудила своє, своє осуєћено мнънієе о Кралю никоме казати, али іой врло быяше жао, што место прекраснога лица, коє є у памети држала, намрштенъ образъ съ гордымъ погледом усмотри (А. Обреновић, Уранија, 1837; према Цветковић ТЕофиловић 2006: 482). 
Поред тога, гомилањем славенизама тежило се већој експресивности језичког израза (в. Цветковић 2006; ИвАновић 2020):

Стихіє: вода, ватра, и самъ воздухъ на бурноме мору, быяу му, колико су игда могле, вредъ и штету причиниле, и иманъ нъгово прогутале (Д. Исаиловић, Уранија, 1837; према Цветковић ТЕофиловић 2006: 480).

3.5. СЛАВЕНИЗМИ КАО ОДРАЗ ИДИОЛЕКТА ПОЈЕДИНИХ СТВАРАЛАЦА. КОНачНО, кад је реч о текстовима књижевноуметничког карактера, не би требало изгубити из вида и то да су изрази многих аутора 18. и 19. века (нпр. Л. Мушицког (ЋАловић 2013), Ђ. М. Кодера, Ј. Суботића (МилАновић 2013: 180-191; 2014: 326); и др.) окарактерисани упадљивијим присуством славенизама као обележјем њиховог иняивияуалної стила и свесної односа према традицији, што свакако не треба занемаривати када је реч о статусу и функцији славенизама у пред- и довуковским временима.

4. ПуьлицистикА. Будући да новинарски поджанрови често подразумевају јасну и униформну структуру, у рецентнијим испитивањима публицистичких текстова код Срба у 18. и 19. веку указивано је на неодвојиву везу њиховог језика и тематско-структурне организације текста (в. БЈЕЛАковић 2012a; МилАновић - БЈелАковић 2016). Сасвим очекивано, дата зависност рефлектује се и на употребу славенизама, за коју се показало да се налази у корелацији како са појединим (1) структурним сегментима новинских поджанрова тако и (2) са њиховом тематском раслојеношћу.

4.1. СТРУКТУРНА ОРГАНИЗАЦИЈА НОВИНСКИХ ПОДЖАНРОВА И УПОТРЕБА СЛАВЕНИЗАМА (НА ПРИМЕРУ ВЕСТИ И НЕКРОЛОГА)

4.1.1. Вести. Стилско-структурна специфичност савременог новинарског дискурса вести подразумева постојање следећих елемената: наслова (и йоgнаслова), иллаве и йела вестии (AGGARWAL 2006: 85). Узимајући у обзир структурну организацију вести у првим српским новинама ${ }^{9}$ (Серйскија йовсеяневнија новини (СПН, 1791), Славеносерйскија вјеgомосиии (ССВ 1792; 1793) и Новине срйске (НC, 1813-)), истраживања показују да се славенизми у њима у највећој мери везују за наслове и поднаслове (в. БЈЕлАковић 2012а: 56-57):

${ }^{9}$ Иако у савременој публицистици наслови и поднаслови имају изузетно важну улогу јер им је примарна функција привлачење пажње читалаца (VAN DIJK 1985: 78; AGGARWAL 2006: 85), они у првим новинама код Срба у 18. и 19. веку носе информацију о жанру (нпр. Смесица, Приключенїе, Анекдота, Некрологъ и сл.), или о месту и датуму реализације догађаја о којем је реч (Хунгарїа; Трансилванїя; Францїа; Изъ Лондона Іулїа 2га, и сл.), док се веома ретко срећу наслови „сензационалистичког типа“. Поред тога, требало би истаћи и то да глава вести у савременом смислу (кратки подаци о догађају који су издвојени из тела вести) није посведочена у анализираним новинама и може се само условно реконструисати. Више о структури новинске вести код Срба у 18. и 19. веку в. у БЈелАковић 2012; МилАновит 2013: 252-265. 
Цесаро-кралевскїя держави (ССВ, 28. 12. 1792); Инностранна Приключенїя (ССВ, 28. 12. 1792); Приключенїя отечественна (НС, 6. 9. 1813); Политическа приклученїя. Енглезска (НС, 13. 10. 1815; 3. 1. 1816); Приключенїя внутрення. Вїена (НС, 15. 7. 1814; 9. 5. 1816; 4. 4. 1817); и сл.,

док се у телу вести могу довести у везу пре свега са одређеним тематским блоковима, не и са стуктурним елементима (в. поглавље 4.1.2.). Оваква употреба славенизама на хронолошкој оси није стабилна. Временом долази до веће србизације те се, на пример, у поднасловима Новина срӣских уочава постепено, али видно продирање народних форми (в. БЈелАковић 2012а: 56-57):

У вторникъ 27. марта 1817 (НС, 24. 3. 1817); У недълю 18. февруара 1817. (НС, 17. 2. 1817); У понедълникъ 14 маїя 1817. (НС, 12. 5. 1817); и др.

\subsection{2. НЕкРолози. У композиционом смислу, некролози представљају} новински жанр у којем су забележени подаци о околностима, животу, раду и заслугама недавно преминуле особе (HuME 2000: 23; EID 2002: 22-24; MoseS - MARELL 2003: 123-125). Као један од најекспресивнијих публицистичких жанрова, некрологе у првим српским новинама одликује узвишен, понекад и патетичан тон, који се постизао активирањем не само синтаксостилема и стилских фигура него и одговарајућих лексичких и синтаксичких средстава, ${ }^{10}$ међу којима важну улогу имају и славенизми - као маркери горњег лексичког слоја:

„На лексичком плану функцију стилема првенствено преузимају славенизми из сфере апстрактне лексике [...]. Поједини славенизми, попут лексеме йолза и изведенице йолезан, у некролозима прерастају у симболе, а остали својом фреквенцијом и бројношћу језички издвајају некрологе од других жанрова у $H C$ : смертїю, почитанїя, достойньйшегъ, рожденъ... (1813); Общества, Гражданиномъ, смертїю, добродътельи, благодарити... (1815); Госпожа, благородна, благодътельницомъ... (1817)“ (МилАНОвИЋ - БЈеЛАКОвић 2016: 209).

Славенизми у некролозима показују изразиту тенденцију ка концентрацији у оним доменима који се односе на (1) идентификацију преминуле особе (њеног друштвеног статуса и значаја):

...похити намъ смертїю неумитномъ 65 льтна почитанїя нашегъ достойнъйшегъ старца Сербина Г. Іакова отъ Сечанацъ (НС, 1813); ...умре намъ о кньижеству Сербскомъ достойно заслужанъ Сербинъ, и найстарій Общества Сербскогъ у граду Трїесту Сочленъ, Георгїй Теодоровичъ (НС, 1815);

10 Више о структури некролога у новинским текстовима Срба 18. и 19. века в. у МиЛАНОВИЋ-БЈЕЛАКОВИЋ 2016. 
и/или на (2) њене заслуге:

Отечестволюбива сердца усердно є Онъ свему ономъ поспђшавао, што бы собратїю Єго Сербле сретьнїимъ учинити могло, кое $є$ найветьма у Темишварскомъ Собору освъдочїо. Чувствителанъ будутьи убоге $\epsilon$ подкреплявао, потребитымъ давао, немотьне помагао, очаявше избавляо и утьшавао, и гди бы годъ присуствовао, свуда сретьне око себе люде чинїо. Колико є грозны суза Фамїлїа ньгова за нимъ излила, толико га више Родъ Сербскій прегорети неможе, правый бо и искренный Рода и Отечества Любитель быяше!! (НC, 1813). ${ }^{11}$

4.2. ТЕМАТСКА РАСЛОЈЕНОСТ НОВИНСКИХ ПОДЖАНРОВА И УПОТРЕБА СЛАВЕНИЗАМА. Израженија употреба славенизама уочена је у оним деловима новинских текстова који реферишу о следећим тематским пољима: ${ }^{12}$

a. представници највишег друштвеног слоја, називи за високе државне функције и институције: Єго Сщ єнЕйшєє Щ К Іипєраторсккоє Велнчество (CПН, 14. 3. 1791); и донесао Его Величеству радостно извђстїе от Княза Кобурга (ССВ, 3. 5. 1793); Всемилостивђишїй Царь Аустрїйскїй подарїо $є$ Насльдному князу Шведскомъ (НС, 9. 9. 1813); Генераллїетнантъ Князь Горчаковъ... (НС, 16. 8. 1813); ...да Канцеларїи военога Мїнїстерства чрезъ гражданско началство Правителства (НС, 16. 8. 1813); $\underline{\text { Сa }}$ Крал. Высочество, Насльдна Княгина Баварска съ Князомъ нънимъ... (HC, 18. 8. 1813); госпоже Ерцхерцогинь и Велике Княгинъ (НС, 7. 10. 1814); Министеръ внутренньи дъла (НС, 5. 5. 1816); У ц.кр. Величествомъ за Државнога и Конференц-Министра, скупа верховнога канцлера и Министра внутреннихъ Дълъ наименованныи... (НС, 22. 12. 1817); и др.

б. сакрална сфера (називи богомоља, црквених празника, светитеља, богослужења): ...на данъ рождєства Хрнстова (СПН 19. 12. 1791); цєєковъ (СПН 19. 12. 1791); қогослүжєнїє (ССВ, 31. 12. 1792), Папа э у Церкви Святаго Петра служїо (ССВ, 4. 1. 1793); богомоленїя (ССВ, 21. 6. 1793); богослуженїю (НС, 14. 10. 1813); и др.

в. подаци о времену: днесъ (ССВ, 1.4.1793); сихъ днехъ (ССВ 5. 11. 1793); вчера (ССВ, 12. 11. 1793); и др.

г. лексема апстрактног значења и терминологија (војна, административна и сл.): ү посльАствнїю (СПН 19. 12. 1791); ощущєнїєцъ (СПН, 1.4.1791);

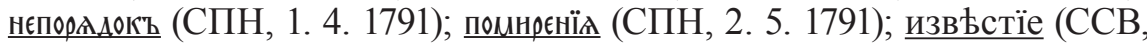
12. 11. 1793); подворение (НС. 1. 7. 1814); отрицанїя (НС, 3. 11. 1815); союзницы $(\mathrm{HC}, 14.8 .1815) .{ }^{13}$

${ }^{11}$ Више о лексичким стилемама у некролозима првих српских новина в. у МилАновић - БЈЕЛАКОВИЋ 2016.

12 Подаци су преузети из БЈЕлАКовић 2012; МилАновић - БЈЕЛАКовић 2016. Наведеним примерима одговарају и они дати у поглављу 4.1.1.1. у овом раду.

${ }^{13}$ Временом, и у ове тематске блокове, уз славенизме, постепено продиру домаће форме: данасъ (СПН, 6. 5. 1791); юүєръ (СПН, 8. 8. 1791), данас (НС, 1. 10. 1813); Католическїи Свещенницы 
4.3. КОНТАКТНИ СИНОНИМИ У НОВИНСКИМ ТЕКСТОВИМА И СТАТУС СЛАВЕНИзАмА. Како би се задовољио вкус читиалащӣва, уредници новина често су прибегавали употреби контактних синонима - сукцесивном низању две истозначне лексеме (или више њих), покушавајући тиме да обезбеде потпуну семантичку прозирност стране или новоуведене домаће/словенске лексике. У овом поступку славенизми су често добијали позицију објаснидбене другопозициониране лексеме, нпр. монархија (јеgноgержастиво); библио-

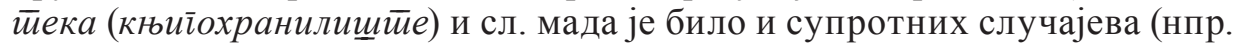
оружјахранилищйе: арсенал) (в. МилАновић 2013: 211-226). Оваква употреба представља још један у низу показатеља односа традиционалиста према славенизмима, које они нису доживљавали као страну лексику, него као део српског и општесловенског културног наслеђа, односно као богату ризницу која је омогућавала лексичку елаборацију тадашњег књижевног језика у пуном смислу.

5. НАукА. У духу просветитељског утилитаризма, а из жеље да српској јуности приближе опште токове европске научне мисли, српски културни трудбеници 18. и 19. века преводе низ књига научног профила, наилазећи у том послу на незанемарљив проблем - недостатност у терминологији. Једно од решења које се показало успешним, а којем су они прибегавали, била је употреба славенизама као својеврсног одраза оновременог пуризма, који су - уз интернационализме и германизме - полако градили терминолошки апарат тадашњег књижевног језика Срба. ${ }^{14}$

Рецентније потпуније анализе термино-система појединих научних дисциплина - математичке географије и картографије (в. БЈелАковић 2017б) и лингвистике (МАцАновић 2018) указују на готово идентичан статус славенизама у језику науке тог времена:

1. број терминолошких славенизама на почецима научне делатности Срба у 18. веку далеко је већи него онај посведочен у делима научног карактера од педесетих-шездесетих година 19. века (в. БЈЕлАКовић 2017б: 52; МАцАновић 2018).

2. иако су се интернационализми показали као најотпорнија лексичка скупина у српском терминолошком систему 18. и 19. века (в. БЈеЛАКовић 2012б), поједини славенизми послужили су као основа, која је након посрбљавања заживела и у потоњим временима: созвезgије $\rightarrow$ cазвежђе; време буgушиче $\rightarrow$ буgуће време; и сл.

Ипак, највећи број посрбљених славенизама није преживео. Уступио је место интернационализмима или домаћим кованицама (в. БЈелАковић 2017а; МАцАновић 2018): возяухокружије : вазяухакружје : аймосфера; времја

(НС, 5. 1. 1816); у саборной цркви (НС, 5. 4. 1816); 4 свештенника (НС, 11. 4. 1817); и сл.

${ }^{14}$ Наведени систем настао је као резултат стихијског и неинституционализованог рада појединаца, што је временом довело до потребе за његовим уједначавањем и оснивањем Друштва српске словесности, о којем овом приликом неће бити речи. 
ирехолјашче $\rightarrow$ време иррехоgеће : иромло време / иерфекай; уgареније $\rightarrow$ ygaрање $\rightarrow$ уgар: акценати, найласак; и сл.

5.1. КОНТАКТНИ СИНОНИМИ У НАУЧНИМ ТЕКСТОВИМА И СТАТУС СЛАВЕНИЗАМА. У научним текстовима посведочена је, такође, употреба контактних синонима, али - за разлику од публицистике - славенизми у њима чешће заузимају примарну позицију, док страни термин добија функцију експликатора потенцијалне семантичке непрозирности славенизма: нпр. земљеоиисаније или іеоїрафија; равнитељ (aequator) и сл. (в. БЈелАКовић 2017a: 310-311).

6. АДминистрацијА. Анализе црквеноадминистративне и пословноправне преписке Срба у 18. и 19. веку на територији Јужне Угарске, Црне Горе и Боке указују на присуство тематски и социјално стратификоване интратекстуалне хомогене диглосије (в. БЈЕЛАКОВИЋ 2019а; 2019б; 2020; БЈЕЛАКОВИћ - Нинковић 2020). Приликом избора одговарајуће форме из вишег или нижег регистра (књишког или народног) статус адресанта и адресата имао је, дакле, важну улогу, те се већи број књишких елемената (па и славенизама) уочава у оним документима у којима је макар један учесник у преписци (адресат или адресант) представник високог свештенства или виђенијег грађанства (в. МлАдЕновић 1987: 227; БЈЕЛАКОвИћ 2019а; 2019б; 2020).

Ако се обрати пажња на садржај анализираних текстова, уочава се (очекивана) тенденција ка концентрацији славенизама у следећим тематским пољима:

1. религиозна тематика у најширем смислу: со-братїями (1749; 1750); васа братїя (1750); $\overline{\text { w}-в а ш е г о ~ Б л а г о р о д і ̈ я ~(1750) ; ~ п р е ћ е ~ в о с к р е с е н і ̈ я ~(1750) ; ~ з а-~}$ васегдашнее поминанї (1778); $\widetilde{w}$ пречестньишаго [...] оца (1775); за утъшенїе Сщеническо (1775); отъ Господа Бога Вседержителя (1831); благодарећи всевышныму (1831), Всевишный Творецъ (1832) ваше Высокоблагородіе (1830); Вашегъ Преосвященства (1832); и др.

2. државне институције, представници виших слојева друштва: Отечества (1830; 1831); державе (1831); Управленіе Народнь (1831), совътницы (Senatori), a 164 исполнительи (polizia) (1831); Правителствующега сената (1838); Сіятельньйшій графъ (1830); ...нашега благочестовога Царя Николая (1830); Княжевство (1837); Свђтльйшій князь (1837); и сл.

3. апстрактна лексика: намъреніе (1830); наставленіе (1830); Високопочитаніемъ (1837); поколебимости (1831), надежду (1831); преставленію (1832); магновенію (1832); удоволствіемъ (1833); союзу (П 32 1835); сочиненія (1837); подруганиіе (1837); благочестіемъ (1837); ща удовлетвореніє (1839); вліянія (1839); и др.

4. део устаљених формулација и изоловани лексички наноси: за-дввовъ вашє мняостн (1727); вєлнколюбєзннмь (1736); да-е ${ }^{c}$ те на-знанїе (1722); већега верованї̈а ради (С 1722); сотворили любовъ (1734); потврждую именом (1734); болшаго верованїя ради (1738);имаюћи нам ьреніе (1830); с нетерпьливостію (1831); ... што скоріе да соверши судейско дђло верху два хапсеника (1831); ... имамъ честь Вамъ обявити, како се [...] находе у согласію (1831); у дъйствие привести (1838); ...изволи ми дати удовлетвореніє (1839); и др. 
5. подаци о времену и месту издавања документа: день (1734); 15. јануарїа 1775. по гречески (1775); во 24 іулїа (1750). ${ }^{15}$

Ово, наравно, не значи да се у овим семантичким скупинама не појављују и форме на народном језику.

6.1. Узимајући у обзир структурну организацију докумената, уочено је да се књишке црте видно концентришу у следећим сегментима (в. БЈЕЛАковић 2019а; 2019б; 2020):

(1) у почетним деловима - у протоколу (у инвокацији - призиву божијег имена, у инскрипцији и интитулацији - навођењу адресата и адресанта, у експозицији - мотивацији за издавање списа) и

(2) на крају - у есхатоколу (у короборацији - закључној потврдној формули; апрекацији - призиву благослова божијег, приликом навођења имена сведока и у хронотопу - времену, месту и потпису).

Уколико је реч о млађем типу епистоларног дискурса, славенизми се бележе пре свега у уводним и завршним формулацијама (в. БЈЕлАковић 2020; БЈЕЛАКОвИћ-НинкОвић 2020).

Коначно, узвишена интонираност коју славенизми сами по себи носе сигурно је утицала на њихов избор у тренуцима када се желео постићи интензивнији стилски ефекат (в. нпр. у посланицама Петра I Петровића Његоша; в. Ивановић 2020).

7. ЗАкључАк. Наведени синтетички преглед употребе славенизама у различитим жанровима сасвим јасно указује на једну изузетно комплексну ситуацију, у оквиру које можемо издвојити неколико параметара који имају статус активатора славенизама, а у чијој основи леже два (понекад неодво-

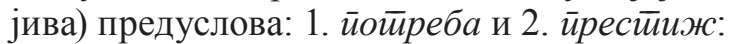

(1) СТРУКТУРА ТЕКСТА (наслови, поднаслови, посвете, предговори, спискови пренумераната, уводне и завршне формулације (у кореспонденцији));

(2) ТЕМАТИКА ТЕКСТА У ЦЕЛИНИ И ЖАНР (Текстови Ненаративног профила);

(3) ПРАГМАТИКА (1. контекст - јавна комуникација, школа и сл., 2. социјална стратификација - представници виших друштвених слојева, 3. институционализованост; 4. устаљене формулације и сл.);

(5) идиолект аутора и њихов однос према традицији;

(6) сЕмАнтикА (сакрална, апстрактна лексика, терминологија, титуле, институције, хронотоп, и сл.);

(7) стилогеност (експресивност, комични ефекти, карактеризацији ликова).

Иако временом бивају посрбљени, маргинализовани или искључени из система српског књижевног језика, славенизми се у незанемарљивом броју бележе и у другој половини 19. века-пре свега у домену религиозне тематике (в. ЦветкОвић 2005; МилАновић 2014: 325).

15 Наведени примери преузети су из БЈЕлАковић 2019а; 2019б; 2020. Кореспондентна употреба славенизама регистрована је у другим текстовима сличног профила (нпр. у посланицама Петра I Петровића Његоша (в. ИвАновић 2020), у преписци В. Стеф. Караџића, нарочито у оној до 1818. године (в. ЈовАновић 1987) и др.). 


\section{ИЗВОРИ}

ОБРАдовић 1788: Езойове и йрочихъ разнихъ баснойвориевъ, съ различни езика на славеносербски езикъ ирревеgене, саgъ йрви реgъ съ наравоучииеелними йолезними изясненіами и настиавльніами изяайе и сербскои юностии йосвећене басне. У Лайпсику, 1788. (прир. Д. Обрадовић).

СПН: Сербскїл йовсеяневныл Новины. Въ Вїенни. 1791.

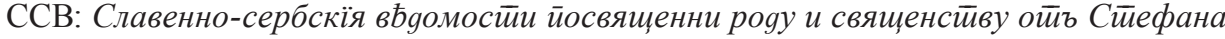
Новаковичъ дворскайо аіенита. Въ Вђннђ.1792, 1793.

НС: Новине сербске изь ијарсӣвующеі̄а ірраgа Вїенне. 1813, 1814, 1815, 1816, 1817.

Поповић, Јован Стерија. Милощь Обилићь: юначко йозорищйе у иетйь деисиивія / сочинено Іоанномъ С. Поповичемъ мудролюбія слушателемъ. У Будиму, 1828.

Поповић, Јован Стерија. Лажа и йаралажа: весело йозорищйе / Сочинено Іоанномъ С. Поповичемъ. У Будиму, 1830.

Поповић, Јован Стерија. Поконяирена тииква: весело Позорищйе у иири дейсиива / составлено одъ Іоанна С. Поповича. У Новомъ-Саду, 1838.

\section{ЦИТИРАНА ЛИТЕРАТУРА}

БЈелАковић, И. Језик новина код Срба крајем XVIII и почетком XIX века. An den Anfängen der serbischen Philologie. На иочецима срйске филолоїије. Сало gебелоїа јера либо азбукойроӣрес Саве Мркаља (1810-2010). Hrsg. Gordana Ilić Marković, Anna Kretschmer und Miloš Okuka. Frankfurt am Mein: Peter Lang. Internationaler Verlag der Wissenschaften, 2012a, 49-80.

БЈЕЛАКовић, И. Процеси у формирању географске терминологије у предстандардној

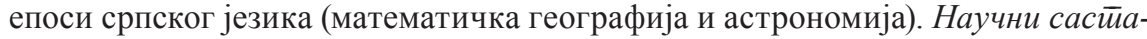
нак славистиа у Вукове яане 41/1 (2012б): 297-308.

БЈелАковић, И. Г. Синонимија у терминологији код Срба у 18. и 19. веку (математичка географија и астрономија). Словенска йерминолойја gанас. Београд: САНУ. Књига CLXVII. Одељење језика и књижевности. Књига 28. Предраг Пипер и Владан Јовановић (ур.), 2017a, 305-315.

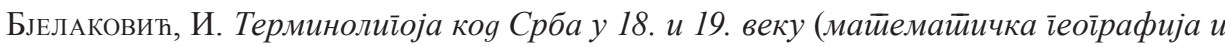
карӣоірафија). Нови Сад: Два пера, $2017 б$.

БЈеЛАКовић, И Г. Језик докумената Архива манастира Савине (18. век). Срӣско језичко и кьижевно насљеђе на ирростиору gанащње Црне Горе. Сриски језик и књижевности

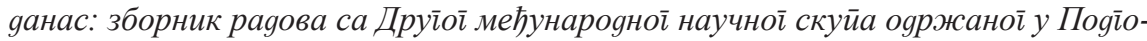
рици 26-28. маја 2017. і̊guне. Ј. Стојановић (ур.). Подгорица: Матица српска Друштво чланова у Црној Гори; Нови Сад: Матица српска; Бања Лука: Матица српска - Друштво чланова Матице српске у Републици Српској, 2019а, 515-526.

БЈелАковић, И. Језик докумената Архива Српске православне епархије будимске у Сентандреји (прва половина 18. века). Језичке јеgинице срйской језика у сисйе-

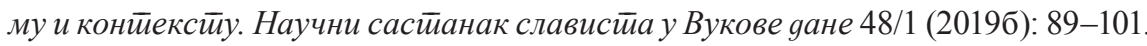


БЈелАковић, И. Г., Ненад Ђ. Нинковић (2020). Пословноправна преписка српских капетана из Јужне Угарске (Национални архив у Сегедину, 1727-1746). 3борник

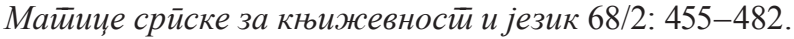

БЈелАковић, И. Г. Елементи славеносрпског у језику Његошевих писама. Њейомев зборник Майице срӣске. 4. Нови Сад: Матица српска, 2020, 103-126.

ДАБић, Б. Русизми и славјанизми у лексици „Луче микрокозма“. Лексикоірафија u лексиколоїија. Зборник раяова. Београд - Нови Сад: Матица српска - Институт за српскохрватски језик, 1982, 47-52.

Зорић, Милена С. Неколико речи о статусу и идентификацији славенизама. Зборник

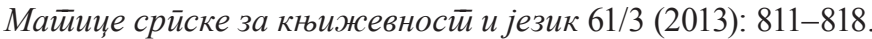

Зорић, М. Славенизми у раним драмама Јована Сйерије Пойовића. Нови Сад: Матица српска, 2018.

Ивановић, М. Којим је то језиком писао Св. Петар Цетињски. Срйски језик XXV (2020): 563-580.

Ивић, П. Прейлеg ист̄орије срӣской језика. Сремски Карловци - Нови Сад: Издавачка књижарница Зорана Стојановића, 1998.

Ивић, П. Срйски нароg и њеі̄ов језик. Сремски Карловци - Нови Сад: Издавачка књижарница Зорана Стојановића, 2001.

ЈовАновић, Г. Славенизми у Вуковој преписци. Зборник раgова о Вуку Сӣефановићу Караиићу. Сарајево, 1987, 177-182.

Јовић, Н. Славенизнми у Сремчевим делима. Кюижевно gело Сиевана Сремца-ново чийаъе. Лингвистичка секција. Зборник радова, Ниш: Центар за научна истраживања САНУ, 1997,

КлАић, др Б. Језична проблематика у неким комедијама Јована Стерије Поповића.

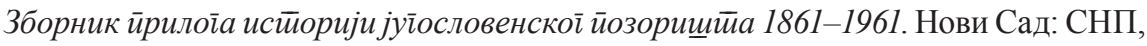
1961, 73-130.

КречмеР, А. О књижевнојезичкој традицији до 1800. код Срба и Руса (размишљања о словенској историјској стандардизацији). Јужнословенски филолої LVI/1-2 (2000): 543-559.

МАксимовић, Г. Комедиографски поступак Јована Стерије Поповића. Научни сасӣ $а$ нак славистиа у Вуквое дане 35/2 (2006): 201-212.

МАцАновић, А. Срйска језикословна йерминолоіија у 19. веку. Београд: Институт за српски језик САНУ, 2018.

МилАновић, А. Језик весма йолезан. Београд: Друштво за српски језик Србије, 2013.

МилАновић, А. Језик Јована Субот̄ића. Београд: Чигоја штампа - Филолошки факултет, 2014.

МилАновић, А., И. БЈелАковић. Толстојева периодизација и питање жанра. Slavische Geisteskultur: Ethnolinguistische und philologische Forschungen. Теil 2. Славянская духовная культура: этнолингвистические и филологические исследования. Часть 2. Zum 90. Geburtstag von N. I. Tolstoj. Philologica Slavica Vindobonensia. Band 3. A. A. Alekseev et. al. (hrsg.). Frankfurt am Mein: Peter Lang. 2016, 197-217. 
МлАденовић, А. Славеносрпски елементи у језику дела „Роман без романа“ Јована Стерије Поповића. Зборник за филолойију и линівисӣику XXV/1 (1982): 121-139.

МлАденовић, А. Карактер језика неких писама будимског епископа и карловачког митрополита Вићентија Поповића из првих деценија XVIII века. Сенӣандрејски зборник. 1. Д. Медаковић (ур.). Београд: Српска академија наука и уметности, 1987, 225-236.

Младеновић, А. Славеносрӣски језик. Сӣуgије и чланции. Нови Сад - Горњи Милановац: Књижевна заједница Новог Сада - Дечје новине, 1989.

Ромчевић, Н. Ране комеgије Јована Сӣерије Пойовића. Библиотека Позоришна култура на тлу Војводине. Књ. І. Нови Сад: Позоришни музеј Војводине, 2004.

Стијовић, С. Славенизми у Њеїощевим иеесничким делима. Сремски Карловци - Нови Сад: Издавачка књижарница Зорана Стојановића, 1992.

Суьотић, Љ. Језик Јована Хаиића. Нови Сад: Матица српска, 1989.

Суьотић, Љ. Доситејеве Басне и Наравоученија: (језичка анализа - релативне реченице). Гояищњак Филозофскоі факулитейа у Новом Саgу. 23 (1994): 45-51

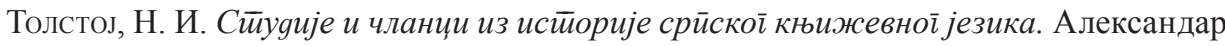
Младеновић (прир.). Београд - Нови Сад: Завод за уџбенике и наставна средства - Вукова задужбина - Матица српска, 2004, 65-147; 199-207.

ЋАловић, Б. Славенизми у поезији Лукијана Мушицког. Прилози ироучавању језика 44 (2013): 1-27.

УньегАун, Б. Почеции књижевной језика коg Срба. Београд - Нови Сад: Вукова задужбина - Орфелин - Матица српска, 1995.

Цветковић, И. Славенизми у Вуковом Сритском рјечнику из 1852. године. Зборник Майице срйске за филолойију и линіивитиику XLVIII/1-2 (2005): 95-108.

Цветковић, И. Народне речи и славенизми као синоними. Гоgищњак за срииски језик и књижевности XX/8 (2006): 477-486.

$*$

Aggarwal, V. B. Essentials of Practical Journalism. New Delhi: Concept Publishing Company, 2006.

EID, M. The World of Obituaries: Gender Across Cultures and Over Time. Detroit, Michigan: Wayne State Univ. Press, 2002.

Hume, J. Obituaries in American Culture. University Press of Mississippi, 2000.

Kuna, H. Jezičke karakteristike književnih djela Dositeja Obradovića. Sarajevo: Akademija nauka i umjetnosti Bosne i Hercegovine, 1970.

Moses, R. A., G. D. Marelli. Obituaries and the Discursive Construction of Dying and Living. Proceedings of the Eleventh Annual Symposium about Language and Society. Linguistic Forum 47 (2003): 123-130.

Subotić, Lj. Kojim je to jezikom pisao Sterija? Sava Anđelković i Paul-Louis Thomas (Prir.). Jovan Sterija Popović - klasik koji nam se obraća. Radovi sa Međunarodnog naučnog skupa održanog 24. i 25. marta 2006. godine na Univerzitetu Pariz IV - Sorbona. Vršac: KOV, 2006, 17-40. 
VAN Disk, T. Structures of News in the Press. Discourse and Communication. New Approaches to the Analysis of Mass Media Discourse and Communication. Berlin - New York: Walter de Gruyter, 1985.

Isidora G. Bjelaković

Milena S. Zorić

\section{LEXICAL SLAVENISMS AND THE ISSUE OF GENRE IN THE SLAVONIC-SERBIAN LANGUAGE}

Summary

Having in mind the fact that the research of Serbian literary linguistic idiom from the $18^{\text {th }}$ and $19^{\text {th }}$ century indicates that slavenisms were not used only when it was necessary to fill in the so-called onomasiological gaps, but their use had a particular stylistic function, the central issue of this paper is the issue of the functionalization of slavenisms and their relationship towards the genre (literary artistic, publicistic, administrative and scientific), primarily in Slavic Serbian texts, with a short introduction regarding various interpretations of this concept in Serbian studies. Having in mind the fact that the research of Serbian literary linguistic idiom of the $18^{\text {th }}$ and $19^{\text {th }}$ centuries has been fragmentary, the paper offers both a synthetic view of what has been established in the field so far and it also indicates possible future tendencies in those genres that have so far not been the subject of a more detailed analysis.

Др Исияора Г. Бјелаковић

Универзитет у Новом Саду

Филозофски факултет

Одсек за српски језик и лингвистику

Др Зорана Ђинђића 2, 21000 Нови Сад

isidora.bjelakovic@gmail.com

Др Милена С. Зорић

Висока школа струковних студија за образовање васпитача у Новом Саду

Петра Драпшина 8, 21000 Нови Сад

milena_zoric_ns@yahoo.com 